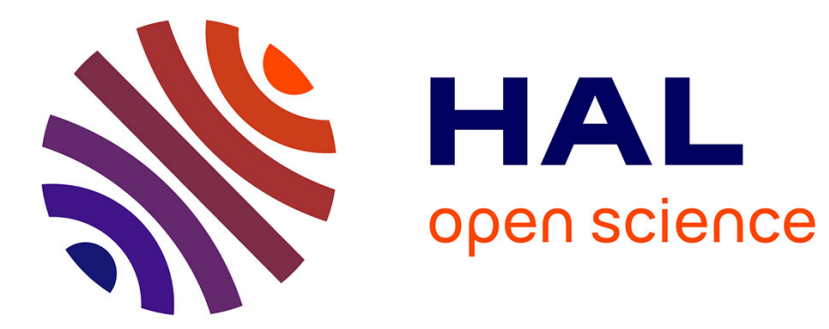

\title{
Is payout policy part of the corporate governance system? The case of France \\ Céline Du Boys
}

\section{To cite this version:}

Céline Du Boys. Is payout policy part of the corporate governance system? The case of France.

European Journal of International Management, 2009, 3 (1), pp.42-59. hal-01290737

\section{HAL Id: hal-01290737 \\ https://hal.science/hal-01290737}

Submitted on 17 Feb 2017

HAL is a multi-disciplinary open access archive for the deposit and dissemination of scientific research documents, whether they are published or not. The documents may come from teaching and research institutions in France or abroad, or from public or private research centers.
L'archive ouverte pluridisciplinaire HAL, est destinée au dépôt et à la diffusion de documents scientifiques de niveau recherche, publiés ou non, émanant des établissements d'enseignement et de recherche français ou étrangers, des laboratoires publics ou privés.

\section{(1)(1) $\$(0)$}

Distributed under a Creative Commons Attribution - NonCommercial - ShareAlikel 4.0 


\title{
Is payout policy part of the corporate governance system? The case of France
}

\author{
Céline du Boys
}

\begin{abstract}
This paper examines the place of payout policies in governance systems. It analyzes the conditions in which payout is used to regulate agency conflicts and studies the relations between dividend or share repurchase and the other governance mechanisms.

Through the study of 167 French firms from 2000 to 2005, the author shows that in France payout is not used to regulate conflicts between majority and minority shareholders, but rather to limit free cash flow risk or conflict between managers and shareholders. In presence of a majority shareholder, the governance systems do not achieve in forcing insiders to disgorge cash.

The study confirms the substitutability between debt and payout and shows that blockholders have an effect on payout. On the contrary, board's characteristics, except the directors' independence, do not influence payout.
\end{abstract}

Key words: France; payout policies; governance mechanisms; dividends; share repurchases; agency relationships; majority and minority shareholders; boards of directors; ownership structures; panel data analysis. 
This paper aims at analyzing the corporate governance role of payout policy and understanding its place in the governance system. In theory, dividend and share repurchase can reduce agency conflicts, but are they really used as governance mechanisms? Moreover, their place in the governance systems has not been really analyzed yet. This paper seeks to make up for this gap.

First, it studies the governance role of payout and analyses the conflicts it can regulate: conflicts between managers and shareholders and between majority and minority shareholders.

Then, to understand the place of payout in the governance system, the paper reviews the other governance mechanisms described by the literature. It studies their influence on both conflicts and identifies their relationships with payout.

At last, a model of the use of payout in the presence of an agency conflict is proposed. Thus, the conditions for payout to be used as a governance mechanism are described.

Following this theoretical study, the paper looks at the case of France. It studies the relationships between payout and various governance mechanisms, and analyses the use of payout to regulate agency conflicts in France. This research helps to understand the place of payout policies in the French governance system. Moreover, it enables to catch the reality of its use as a governance mechanism.

This paper is organized as follow. The first section reviews the literature on payout and governance. The second section describes the methodology of our empirical study. And the third section presents and discusses the results of our tests.

\section{PAYOUT AND GOVERNANCE: A THEORETICAL STUDY}

\subsection{PAYOUT POLICY AS A GOVERNANCE MECHANISM}

Theory considers payout as a way to regulate agency conflicts between managers and shareholders. Indeed, payout helps to decrease the risks of external shareholders' expropriation by the managers, as it minimizes the resources at their disposal (Jensen, 1986). It also obligates managers to refinance and therefore to confront themselves regularly with the monitoring of financial markets (Easterbrook, 1984). These models obtain an interesting empirical support, showing that payout can help to regulate conflicts between managers and shareholders.

Research has mainly focused on the classical theoretical framework of the managerial firm. However, these firms are a minority in Continental Europe where shareholding is mainly concentrated (Barca and Becht, 2001). In firms where ownership is concentrated, the risk of minority shareholders' expropriation comes more from the controlling shareholder's behaviour than from managers.

La Porta et al. (2000) suggest that payout can also help to regulate agency conflicts between majority and minority shareholders. But its efficiency is certainly more limited as payout can serve majority shareholders' interests, and thus increase the intensity of conflicts. Indeed, contrary to the non shareholders - managers, controlling shareholders benefit from payout and are not only compelled by it. Because of their large ownership, they are the first collectors of 
dividends. Moreover, share repurchases can help them to consolidate their control (Stulz, 1988).

Therefore, in theory, payout policy is a governance mechanism that regulates conflicts between shareholders and managers, but also conflicts between majority and minority shareholders. But what is its place in the corporate governance system?

\subsection{PLACE OF PAYOUT POLICIES IN CORPORATE GOVERNANCE SYSTEMS}

Payout policy is considered as a governance mechanism by the financial theory. However, few researches have studied its place in the corporate governance system.

To clarify this issue, firstly we identify alternate governance mechanisms that regulate conflicts between shareholders and managers and conflicts between majority and minority shareholders. Then, we study the relationships between payout and those governance mechanisms.

\subsubsection{GOVERNANCE SYSTEM AND CONFLICTS BETWEEN EXTERNAL SHAREHOLDERS, MANAGERS AND CONTROLLING SHAREHOLDERS}

A governance system is the amalgam of mechanisms that enable to regulate agency conflicts within the firm. Literature on corporate governance has mainly focused on managers' behaviour because of their influence on firms' performance. However, in countries where ownership is concentrated, controlling shareholders also have a strong influence on performance and their behaviour must be controlled.

To understand the place of payout policy in the governance system, it is necessary to identify the others mechanisms that can also regulate conflicts between external shareholders, managers and controlling shareholders. According to literature, several mechanisms exist. Internally, managers are monitored by the board of directors, the shareholders and the employees. Externally, they are controlled by the equity market, the debt market, the managerial labour market and the product market. The legislation can also offer an external protection to investors.

Literature has studied the efficiency of those mechanisms in regulating conflict between shareholders and managers, but not conflict between majority and minority shareholders. Therefore, we will discuss here some of the above mechanisms and study their efficiency in the presence of each of these two conflicts.

\subsubsection{BLOCKHOLDERS}

First of all, insiders are controlled and monitored by shareholders. On a legal level, they control managers through shareholders' general meeting. In reality, the power of the latter is limited (Maati, 1999). Monitoring exerted by some shareholders, like blockholders or institutional investors, is much more efficient.

Shleifer and Vishny (1986) describe the particular role of blockholders in monitoring managers. Empirical studies show that the presence of a large shareholder has a positive influence on corporate performance and governance (Shleifer and Vishny, 1997). But links between performance and ownership vary depending on countries or main shareholders' identity. Large shareholders' influence on American firms is weak (Holderness, 2003; Singh and Davidson, 2003), but stronger outside USA (Denis and McConnell, 2003). 
In spite of this literature, the control exerted by blockholders appears to be ambiguous. On the one hand, they can control managers' behaviour and thus help to regulate conflicts. On the other hand, they can extract private benefits if their ownership is large. Their influence is therefore bad for minority shareholders' interests (Morck et al., 1988; McConnel and Servaes, 1990).

The controlling shareholder's behaviour might be monitored by some external blockholders. But, blockholders can also form an alliance with the main shareholder in order to extract private benefits (Maury and Pajuste, 2002). According to La Porta et al. (1999), a second large shareholder helps to limit minority expropriation. But according to Maury and Pajuste (2002), its influence will be function of its identity, its interests and its ability to extract private benefits.

In the United States, activism by institutional investors is influent, and leads to change in governance or investment decision (Smith, 1996; Carleton et al., 1998; Del Guercio and Hawkins, 1999). In France, activism is still not very developed (Girard, 2001).

\subsubsection{BOARD OF DIRECTORS}

In theory, the board of directors or the supervisory board is the first supervisor of managers' decisions (Fama and Jensen, 1983). Constituted of shareholders appointed by the annual meeting, the board is turned towards defending shareholders' interests.

Several characteristics facilitate board monitoring: small size, the fact that it is assisted by committees, or that the functions of chairman and CEO are dissociated. On the contrary, it is difficult to know if a supervisory board is more efficient than a board of directors, or if independent directors have a positive influence on governance.

The table 1 sums up results from the literature about board characteristics efficiency.

Table 1 - Board characteristics: effect and efficiency

\begin{tabular}{|c|c|c|}
\hline Characteristics & Theoretical effect on control & Efficiency \\
\hline $\begin{array}{l}\text { Type of board : } \\
\text { Board of directors or } \\
\text { Supervisory board }\end{array}$ & $\begin{array}{l}\text { Board of directors: easier to dismiss managers. } \\
\text { Supervisory board: dissociate functions of chairman } \\
\text { and CEO. }\end{array}$ & $\begin{array}{l}\text { No difference in efficiency } \\
\text { (La Porta et al., 1998). }\end{array}$ \\
\hline $\begin{array}{l}\text { Dissociation of the } \\
\text { functions of } \\
\text { chairman and CEO }\end{array}$ & $\begin{array}{l}\text { Facilitates dismissal and permit a better monitoring } \\
\text { (Morck et al., 1989). But, in small firms, holding } \\
\text { concurrently both functions favours decision making } \\
\text { (Palmon and Wald, 2002). } \\
\text { No particular effect on performance (Denis and } \\
\text { McConnell, 2003). }\end{array}$ & Depends on firm size \\
\hline Committees & $\begin{array}{l}\text { The presence of committees favours board } \\
\text { independence and improve the quality of information at } \\
\text { the board's disposal (Klein, 1998). }\end{array}$ & Strong efficiency \\
\hline Board size & $\begin{array}{l}\text { Small boards permit a better monitoring, a better ability } \\
\text { to react and favour decision making (Jensen, 1993). }\end{array}$ & $\begin{array}{l}\text { Strong efficiency of small } \\
\text { boards } \\
\text { (Singh and Davidson, 2003) }\end{array}$ \\
\hline $\begin{array}{l}\text { Independence of } \\
\text { directors }\end{array}$ & $\begin{array}{l}\text { Independent directors decrease the risk of managerial } \\
\text { entrenchment and favour board's expertise (Fama and } \\
\text { Jensen, 1983). } \\
\text { But, how independent directors are encouraged to } \\
\text { efficiently monitor managers (Tirole, 2006)? }\end{array}$ & $\begin{array}{l}\text { Strong efficiency in theory, } \\
\text { but empirical support is } \\
\text { ambiguous (Denis and } \\
\text { McConnell, 2003) }\end{array}$ \\
\hline
\end{tabular}


Conclusions about board efficiency have sometimes questioned their present shapes. Jensen (1993) judges they are too slow and not enough efficient. Moreover, board efficiency is strongly limited by managerial entrenchment, by the fact that managers are founders of the company, or by that they have a large ownership (Morck et al., 1989). Thus, it appears that the board is better at monitoring managers than majority shareholders.

\subsubsection{LEGAL PROTECTION OF SHAREHOLDERS}

Law gives outside investors some powers to protect their investment against expropriation by insiders. But the extent of legal protection of shareholders differs enormously across countries. La Porta et al. (1998) show in particular that common law countries appear to have the best legal protection of minority shareholders, whereas civil law countries, and most conspicuously the French civil law countries, have the weakest protection. Indeed, private benefits embezzled by controlling shareholders are much higher, relatively to firm value, in French civil law countries than in common law countries (Nenova, 2003).

Thus, a protective legislation enables minority shareholders to defend their own interests when there is a risk of expropriation by managers or controlling shareholders.

\subsubsection{MARKET FOR CORPORATE CONTROL}

Equity market monitors and controls managers through takeovers (Manne, 1965; Denis and McConnell, 2003). However, takeovers can only be a governance mechanism in firms with dispersed ownership. Thus, the market for corporate control is active in USA or United Kingdom, but is less efficient in countries where ownership is concentrated (Maati, 1999; Denis and McConnell, 2003). Even in the United States, public offers have slowed down since the 1990's (Shleifer and Vishny, 1997).

$\Rightarrow$ In theory, takeovers are an efficient governance mechanism, but the hostility of legislation, the ownership concentration in Europe and the cost of such operations made that this tool is seldom used.

Equity market is also a governance mechanism thanks to its information role. It helps external actors to better estimate the real value of their firm (Maati, 1999). Investors, asset managers, rating agencies or media form an information system that improves quality and accuracy of information and facilitates managers monitoring. In European market, because of ownership concentration, markets' influence is mostly active through this information system.

\subsubsection{DEBT MARKET AND DEBTHOLDERS MONITORING}

Debt is considered as an efficient mechanism in controlling managers' behaviour. Indeed, the risk to go bankrupt (Jensen and Meckling, 1976) or the risk of debtholders intervention in the firm's decisions (Shleifer and Vishny, 1997) urges managers to limit their extraction of private benefits. Moreover, debt decreases free cash flows and thus the risk of minority shareholders expropriation (Jensen, 1986).

The monitoring exerted by debt on managers is likely to also be efficient on majority shareholders' behaviours.

\section{Conclusion about main corporate governance mechanisms}

This review of literature has showed the diversity of governance mechanisms. It has analyzed mechanisms' efficiency to control managers' and majority shareholders' behaviours. 
Internally, managers are monitored by the board of directors and by blockholders. Externally, the legal protection of investors will help minority shareholders to have their interests respected. Markets and debt also offer a good monitoring of managers through their fear to be dismissed and to not be able to guarantee their career plan. These mechanisms offer a variable control of managers' behaviours.

In the presence of a conflict between majority and minority shareholders, only few mechanisms will offer a protection to outside shareholders. Thus, the presence of outside blockholders can facilitate the monitoring of the controlling shareholder. Moreover, the existence of a legislation protective of investors can limit the expropriation of minority shareholders. At last, $\underline{\text { debt }}$ can prompt insiders to limit private benefits.

On the contrary, the risk of a takeover disappears and the efficiency of the board of directors decreases as soon as a shareholder takes the control of the company.

\subsubsection{PLACE OF PAYOUT POLICIES IN CORPORATE GOVERNANCE SYSTEMS}

We now ponder on the place of payout policies in corporate governance systems. To do so, it is necessary to identify the existing relationships between various governance mechanisms and payout. Some mechanisms help minority shareholders to trigger a payout and are considered a complement to payouts. Other mechanisms substitute to payouts.

\subsubsection{BLOCKHOLDERS AND PAYOUT}

Literature has only partially clarified the influence of external blockholders on payout. It does not help to determine if there is a complementary or a substitution relationship between these two mechanisms.

On the one hand, the presence of large shareholders helps to control or supervise the managers or the controlling shareholder. If this control is sufficient to limit the extraction of personal profit, it is not necessary to payout and we can make the hypothesis of a substitution between these two governance mechanisms.

On the other hand, if large shareholders cannot effectively monitor the internal actors, they will push managers to pay out to limit the risks linked to free cash flows. Payout will then be encouraged by their presence resulting in the hypothesis of complementarity between the two mechanisms.

Empirical studies do not let us decide between these two hypotheses. Renneboog and Trojanowski (2005) find a negative relation, sign of a substitution, but, Gugler and Yurtoglu (2003) highlight a positive relation.

Faccio et al. (2001) or Maury and Pajuste (2002) show that large shareholders sometimes join the majority shareholder to profit from private benefits. Blockholders then have a negative influence on payout, but we cannot talk about substitution.

Without clear empirical evidence, it is delicate to determine the direction of the influence of blockholders. This influence varies certainly according to investors and their identity.

\subsubsection{BOARD OF DIRECTORS AND PAYOUT}

Academic literature always considers managers as the decision makers of payout. However, from a legal point of view, the board of directors is the main decision maker of these policies.

In the United States, the amount and frequency of dividend or share repurchase are decided only by the board. In France, the board makes a payout proposal to the shareholders' general 
meeting which must approve it. The role of the shareholders' meeting remains however symbolic since it almost systematically validates the proposals of the board.

From a legal point of view, if the managers are not members of the board, as it is the case in supervisory boards, they do not take part in the payout decision. Actually, their influence is often determining (Brav et al., 2005). Therefore the role of managers is considered as essential by the literature.

While the influence of the board on payout seems determining, little interest is showed by the theoretical research. Few elements enable us to make a hypothesis on the direction of this influence. Payout policy is probably influenced by the quality of its decision maker, but is there a substitution or a complementary relation between these two mechanisms?

Two ways of thinking lead us to think that a complementary relation is the most relevant hypothesis:

- Our first reasoning is liked to the identity of the decision maker of payout policies. Legally, it is the board which holds this role. However, if the board is entrenched, it is the managers who will decide.

According to the hypothesis of substitution, an entrenched board would lead to a high payout. However, it seems difficult to justify that such a board would go against the wishes of the managers or the principal shareholder, and decide to pay out. The effectiveness of the board being limited because of entrenchment, it is likely that the decision will be directly made by the managers and that the payout will be minimal, in accordance with their own interests. On the contrary, an effective board has the capacity to become the decision maker of the payout policy and it would seem astonishing if it then decides not to pay out. We think that these remarks go against the hypothesis of substitution.

- The second reasoning considers the efficiency of the control exerted by the board. According to the hypothesis of substitution, the efficiency of the board would be sufficient to make payouts unnecessary. However, the empirical evidence shows that monitoring by the board is limited, especially in the presence of a main shareholder (Tirole, 2006). Thus, a board should find it beneficial to supplement its control by other governance mechanisms, such as payout policies. Again, that does not bode well for the substitution hypothesis and it leads us to support theoretically the complementary hypothesis.

Some empirical research has analyzed the relation between payout and board's characteristics. They studied the effect on payout of the independence of directors (Farinha, 2003; Hu and Kumar, 2004), of the size of the board or of the large influence of members like the founder (Oswald and Young, 2005).

These studies do not make it possible however to choose between the hypothesis of substitution and that of complementarity. They are mainly interested in the board independence, which remains an element of governance whose effectiveness is disputed, and their results are divergent or not significant.

It seems that new and more advanced empirical tests, including more variables, must be carried out to be able to conclude on the relations between board characteristics and payout policies.

However, upon our theoretical discussion, we suggest that there is a complementary relationship between the efficiency of the board monitoring and payout.

According to literature, a board of quality, therefore effective in its role of governance, is a small board, assisted by committees, where the functions of chairman and CEO are dissociated and where the influence of managers or founders is weak. We consider the 
independence of directors as a pledge of quality, even if there is little empirical evidence on this subject.

Thus, a complementarity between board monitoring and payout means a negative relation between amounts of payout and the size of the board, or the influence of the founder on the board. It also means a positive relation between amounts of payout and dissociation of the functions of chairman and CEO, presence of committees, or independence of the board members.

\subsubsection{LEGISLATION AND PAYOUT}

La Porta et al. (2000) noticed that, when the law protects investors effectively, they are able to put pressure more easily on the managers or the control coalition to obtain payouts. Without this protection offered by the law, payout policies are rarely used. The study of Faccio et al. (2001) confirms the positive influence of investors' protection on amounts of payout.

$\Rightarrow$ Through these studies, legislation appears as a governance tool complementary to payout.

\subsubsection{EQUITY MARKET AND PAYOUT}

Theory makes the hypothesis of a complementarity between the pressure exerted by the market for corporate control and payout policies (Jensen, 1986; Zwiebel, 1996). This hypothesis finds a good empirical support (Page et al., 1996; Billett and Xue, forthcoming).

However, the pressure exerted by the financial market is also the consequence of the monitoring exerted by financial analysts, investors or the various information systems present on markets (Maati, 1999).

Faccio et al. (2001) underline the role of investors in payout decisions. When they locate a risk of expropriation, they devaluate the stock and make the raising of new capital difficult for the company. In order not to obstruct the development of the firm, managers are then forced to pay out. Thereby the risk of expropriation is limited. In return, when this risk is not visible or is weak, the pressure of markets is slackened and payouts decrease.

$\Rightarrow$ The pressure exerted on managers by the stock market encourages payouts. Therefore, there is a complementarity between the two governance mechanisms.

\subsubsection{DEBT AND PAYOUT}

According to Jensen (1986), debt and payout are two substitutable governance mechanisms. Indeed, debt decreases free cash flows and reduces the need of resorting to payout. This substitution is reinforced by the fact that the two mechanisms are expensive and that debt covenants often include clauses restricting the level of dividends.

Empirical studies confirm the hypothesis of substitution between payout and debt. The level of dividend payout is negatively related to the firm's debt (Fenn and Liang, 2001; Hu and Kumar, 2004). The level of share repurchase is also negatively connected to debt (Fenn and Liang, 2001; Weisbenner, 2002; Oswald and Young, 2005). 
Table 2 - Synthesis: Theoretical hypothesis on the relationships between payout and governance mechanisms

\begin{tabular}{|c|c|c|}
\hline GOVERNANCE MECHANISM & RELATION WITH PAYOUT & Notes \\
\hline Law & Complementarity & \\
\hline Capital Markets & Complementarity & \\
\hline Debt & Substitution & Strong empirical evidence \\
\hline Board efficiency & Complementarity (?) & Very limited empirical evidence \\
\hline Blockholders & Changeable influence & $\begin{array}{l}\text { Literature does not agree on the direction of the } \\
\text { relationship. It certainly depends on the identity of the } \\
\text { blockholder. }\end{array}$ \\
\hline
\end{tabular}

\subsection{USE OF PAYOUT POLICY AS A GOVERNANCE MECHANISM}

Dividend and share repurchase are two governance mechanisms. But, their implementation is decided by internal actors who are the ones to be monitored. This observation questions what forces those decision-makers to pay out. Why would they take a decision that could limit the satisfaction of their own interests? Literature has not really handled this problem, as it considers that the amount of pay out always increases in the presence of an agency conflict.

Studying the place of payout policies in the governance system enables to answer this question. Indeed, we deducted from previous researches that mechanisms as markets, legislation or boards of directors help minority shareholders to force the payout. Moreover, some mechanisms also regulate efficiently agency conflicts and so payout doesn't have to be increased. Then, we think that the influence of agency conflicts on payout decisions will depend on the efficiency of corporate governance systems.

In the presence of governance mechanisms complementary to payout, minority shareholders should be able to force internal actors to pay out. On the other hand, in the absence of such mechanisms, it is likely that the internal actors decrease payouts in order to increase cash within their reach and satisfy their own interests.

Moreover, in the presence of efficient substitutable governance mechanisms, it should be less necessary to increase payout when facing an agency conflict.

$\Rightarrow$ Payout decisions are influenced by agency conflicts, depending on the governance system of the firm. Alternate governance mechanisms and agency conflicts play a role in understanding payout policies.

\section{METHODOLOGY OF THE EMPIRICAL STUDY}

To better understand the place of payout policies in governance systems, we now take a look at empirical reality. On the French market, we test the influence of various governance mechanisms on payout policies, and so the hypothesis of substitution or complementarity stemming from our review of literature. Moreover, we study the influence of agency conflicts on the size of payout policies. 


\subsection{SAMPLE SELECTION, DATA SOURCES AND MEASUREMENT OF VARIABLES}

To constitute our sample, we selected the companies belonging to the French SBF 250 index. We collected all available data on payout, shareholding and governance over 6 years, from 2000 to 2005. Thus, our final sample includes 950 observations on 167 companies.

The choice of the French case stops us from comprehending the influence of the law. However, according to La Porta et al. (2000), we consider French legislation as insufficiently protective of minority shareholders.

Moreover, the literature showed the very negligible influence of the market for corporate control in countries where shareholding is concentrated. Thus we consider, in agreement with the literature, that there is a global influence of the markets on firms' behaviour, but it does not go through takeovers.

To measure the intensity of agency conflicts, we use several variables: control concentration, the presence of a majority shareholder, managerial ownership, the power of the main shareholder and the free cash flow risk (measured by cash-flows and investment opportunities).

The following table sums up the measure used for each variable of our model.

Table 3 - Definition of variables

DV = Dummy Variable

\begin{tabular}{|c|c|c|}
\hline \multicolumn{2}{|c|}{ DEPENDENT VARIABLE } & CONSTRUCTION OF THE VARIABLES \\
\hline \multicolumn{2}{|c|}{ Total Payout $=$ Payout Yield } & TXRDT $=($ Net repurchase + Dividend $) /$ Capitalization \\
\hline \multicolumn{2}{|c|}{ INDEPENDENT VARIABLES } & \\
\hline \multirow{6}{*}{ 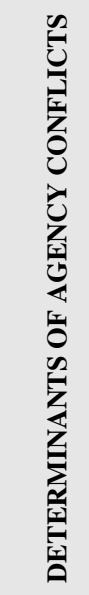 } & Control concentration & - CONCONT $=\%$ of voting rights held by the first three shareholders \\
\hline & $\begin{array}{l}\text { Presence of a majority } \\
\text { shareholder }\end{array}$ & - ACTMAJ : DV = 1 if the first shareholder has more than $33,3 \%$ of the shares \\
\hline & Managerial ownership & - CONTDIR $=\%$ of voting rights held by the main managers \\
\hline & $\begin{array}{l}\text { Power of the main } \\
\text { shareholder }\end{array}$ & $\begin{array}{l}\text { - RAPPOC }=\% \text { of shares of the } 1^{\text {st }} \text { shareholder } / \% \text { of voting rights of the } 1^{\text {st }} \text { shareholder } \\
\text { - PVOIRACT }=\% \text { of shares of the } 1^{\text {st }} \text { shareholder } /(1-\% \text { of floating shares - } \% \text { of } \\
\text { shares of the } 1^{\text {st }} \text { shareholder) } \\
\text { - PVOIR2 : DV }=1 \text { if the chairman or the CEO is one of the three first shareholders } \\
\text { - PVOIR3 : DV }=1 \text { if the main shareholder is one of the founders }\end{array}$ \\
\hline & $\begin{array}{l}\text { Investment } \\
\text { opportunities }\end{array}$ & $\begin{array}{l}\text { - OPPINVT: DV = } 1 \text { if Tobin's Q [measured by: (Capitalization + Debt Value ) / Book } \\
\text { Value] is lower than } 1\end{array}$ \\
\hline & Cash - Flows & - CASHFL = Mean operating income / Mean book value \\
\hline \multirow{3}{*}{ 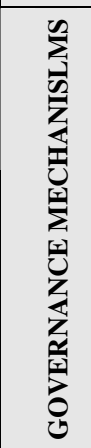 } & Debt & - DETTETOT = Total financial debt $/$ Total assets \\
\hline & Blockholders & $\begin{array}{l}\text { - CONTBLOC2 }=\% \text { of voting rights of the } 2^{\text {nd }} \text { shareholder } \\
\text { - CONTBLOC3 }=\% \text { of voting rights of the } 3^{\text {rd }} \text { shareholder }\end{array}$ \\
\hline & Board efficiency & $\begin{array}{l}\text { - MBRCA = Numbers of directors } \\
\text { - DISSPDG : DV = } 1 \text { if the functions of chairman and CEO are dissociated } \\
\text { - COMITECA }=\text { Number of committees assisting the board (only committees of } \\
\text { remuneration, audit or nomination) } \\
\text { - FONDCA1 }: \text { DV }=1 \text { if the founder of the company is one of the directors } \\
\text { - FONDCA } 2=\% \text { of vote of the founder family } \\
\text { - INDCA = Number of independent directors }\end{array}$ \\
\hline
\end{tabular}




\subsection{METHOD OF ANALYSIS}

To test our model, we used some panel data. The Fisher test and the Lagrange multiplier test showed the existence of specific individual effects in our panel, and rejected the existence of temporal effects. Therefore, beyond the variables considered in this study, each company has specific characteristics which explain its payout decision. The Hausman (1978) test prompts us to model the heterogeneity of the firms' behaviours by a model with fixed effects.

However, the linear regression with fixed effects presents a limit. It does not allow studying the influence of independent variables that do not vary in time. In order to circumvent this limit, it is interesting to complete the intra-individual analysis by an inter-individual analysis. Thus, we complement the estimate of the model with fixed effects by a regression on average data to study the influence of the fixed or quasi fixed variables.

\section{EMPIRICAL RESULTS}

$\underline{\text { Table } 4}$ presents the results of linear regressions with fixed effect of payout yield on our independent variables.

Some variables are quasi stable over our 6 years of study. It is the case of PVOIR2, PVOIR3 and FONDCA1. To appreciate the influence of these variables, it is necessary to use linear regressions made on average data. Results of these regressions can suffer from not controlling firm's behaviour heterogeneity. Meanwhile, it enables us to comprehend the influence of these three variables. Beyond PVOIR2, PVOIR3 and FONDCA1, we include several other determinants of the agency conflicts. The results are presented in Table 5. 
Table 4 - Linear regressions with fixed effect of payout yield

Dependent variable $=$ TXRDT $=$ payout yield .

Independents variables $=$ OPPINVT: dummy variable $=1$ if Tobin's $\mathrm{Q}$ is lower than 1 ; CASHFL $=$ average cash-flows; CONCONT = control of the first three shareholders; CONTDIR = managerial control; ACTMAJ: dummy variable $=1$ if the first shareholder has more than $33,3 \%$ of the shares; RAPPOC $=$ ownership / control of the first shareholder; PVOIRACT = relative ownership of the first shareholder compared to the other known shareholders; CONTBLOC2 $=$ control of the second shareholder; CONTBLOC3 = control of the third shareholder; DETTETOT = total debts; MBRCA = size of the board; COMITECA = number of committees assisting the board; DISSPDG: dummy variable $=1$ if the functions of chairman and CEO are dissociated; INDCA $=$ number of independent directors; FONDCA2 $=$ control of the founders; LOGAPI $=$ size of the firm;

TXRDTEX = dividend yield of the previous year.

\begin{tabular}{|c|c|c|c|c|c|c|}
\hline & (1) & (2) & (3) & (4) & (5) & (6) \\
\hline CASHFL & $\begin{array}{c}0.0253 * * \\
(2.45)\end{array}$ & $\begin{array}{c}0.0283 * * * \\
(2.72)\end{array}$ & $\begin{array}{c}0.0265 * * \\
(2.53)\end{array}$ & $\begin{array}{c}0.0292 * * * \\
(2.78)\end{array}$ & $\begin{array}{c}\text { 0.0244** } \\
(2.12)\end{array}$ & $\begin{array}{c}0.0266 * * \\
(2.29)\end{array}$ \\
\hline OPPINVT & $\begin{array}{c}0.0049 * * * * \\
(3.26)\end{array}$ & $\begin{array}{c}0.0036 * * \\
(2.10)\end{array}$ & $\begin{array}{c}0.0052 * * * * \\
(3.49)\end{array}$ & $\begin{array}{c}0.0038 * * \\
(2.28)\end{array}$ & $\begin{array}{l}0.0048 \text { *** } \\
(3.24)\end{array}$ & $\begin{array}{c}0.00329 * * \\
(2.00)\end{array}$ \\
\hline CONCONT & & & $\begin{array}{l}0.0185 \\
(1.30)\end{array}$ & $\begin{array}{l}0.0155 \\
(1.19)\end{array}$ & & \\
\hline CONCONT $^{2}$ & & & $\begin{array}{c}-0.0273 * \\
(-1.93)\end{array}$ & $\begin{array}{c}-0.0240 * \\
(-1.82)\end{array}$ & & \\
\hline CONTDIR & $\begin{array}{l}0.0105 \\
(0.84)\end{array}$ & $\begin{array}{c}0.00649 \\
(0.54)\end{array}$ & $\begin{array}{c}0.00342 \\
(0.25)\end{array}$ & $\begin{array}{l}0.0000082 \\
(0.00062)\end{array}$ & & \\
\hline CONTDIR $^{2}$ & $\begin{array}{c}-0.00368 \\
(-0.21)\end{array}$ & $\begin{array}{c}-0.00218 \\
(-0.13)\end{array}$ & $\begin{array}{c}0.00932 \\
(0.50)\end{array}$ & $\begin{array}{c}0.00991 \\
(0.53)\end{array}$ & & \\
\hline АСТМАJ & $\begin{array}{c}-0.00542 * * \\
(-2.46)\end{array}$ & $\begin{array}{c}-0.00487 * * \\
(-2.33)\end{array}$ & & & $\begin{array}{c}-0.00504 * * \\
(-2.17)\end{array}$ & $\begin{array}{l}-0.00484 * * \\
(-2.16)\end{array}$ \\
\hline RAPPOC & $\begin{array}{c}0.00569 \\
(0.71)\end{array}$ & $\begin{array}{c}0.00376 \\
(0.49)\end{array}$ & $\begin{array}{c}0.00425 \\
(0.55)\end{array}$ & $\begin{array}{c}0.00241 \\
(0.33)\end{array}$ & $\begin{array}{c}0.00749 \\
(0.96)\end{array}$ & $\begin{array}{c}0.00563 \\
(0.75)\end{array}$ \\
\hline PVOIRACT & $\begin{array}{c}-0.0001 * * * \\
(-4.09)\end{array}$ & $\begin{array}{c}-0.0001 * * * \\
(-4.20)\end{array}$ & $\begin{array}{c}-0.0001 * * * \\
(-3.97)\end{array}$ & $\begin{array}{c}-0.0001 * * * \\
(-4.07)\end{array}$ & $\begin{array}{c}-\mathbf{0 . 0 0 0 1} * * * \\
(-3.84)\end{array}$ & $\begin{array}{c}-0.0001 * * * \\
(-3.91)\end{array}$ \\
\hline CONTBLOC2 & $\begin{array}{c}-0.0416 \text { *** } \\
(-2.88)\end{array}$ & $\begin{array}{c}-0.0393 * * * \\
(-2.81)\end{array}$ & $\begin{array}{c}-0.0344 * * \\
(-2.21)\end{array}$ & $\begin{array}{c}-0.0320 * * \\
(-2.16)\end{array}$ & $\begin{array}{l}-0.0320 * * \\
(-2.31)\end{array}$ & $\begin{array}{c}-0.0315 * * \\
(-2.35)\end{array}$ \\
\hline CONTBLOC3 & $\begin{array}{l}0.0164 \\
(0.74)\end{array}$ & $\begin{array}{l}0.0193 \\
(0.90)\end{array}$ & $\begin{array}{l}0.0233 \\
(1.07)\end{array}$ & $\begin{array}{l}0.0261 \\
(1.23)\end{array}$ & & \\
\hline DETTETOT & & & & & $\begin{array}{c}-0.0115^{*} \\
(-1.86)\end{array}$ & $\begin{array}{c}-0.0133 * * \\
(-2.25)\end{array}$ \\
\hline MbRCA & & & & & $\begin{array}{c}0.0000728 \\
(0.15)\end{array}$ & $\begin{array}{c}0.000244 \\
(0.53)\end{array}$ \\
\hline COMITECA & & & & & $\begin{array}{c}-0.000119 \\
(-0.16)\end{array}$ & $\begin{array}{c}-0.0000362 \\
(-0.049)\end{array}$ \\
\hline
\end{tabular}




\begin{tabular}{|c|c|c|c|c|c|c|}
\hline DISSPDG & & & & & $\begin{array}{c}0.000809 \\
(0.47)\end{array}$ & $\begin{array}{c}0.001000 \\
(0.58)\end{array}$ \\
\hline INDCA & & & & & $\begin{array}{l}0.001 * * \\
(2.26)\end{array}$ & $\begin{array}{c}0.0008^{*} \\
(1.81)\end{array}$ \\
\hline FONDCA2 & & & & & $\begin{array}{l}0.0134 \\
(1.46)\end{array}$ & $\begin{array}{l}0.0106 \\
(1.22)\end{array}$ \\
\hline LOGCAPI & & $\begin{array}{c}-0.00185 * \\
(-1.80)\end{array}$ & & $\begin{array}{c}-0.00184 * \\
(-1.81)\end{array}$ & & $\begin{array}{c}-0.00216 * * \\
(-2.08)\end{array}$ \\
\hline TXRDTEX & & $\begin{array}{c}0.179 * * * \\
(4.16)\end{array}$ & & $\begin{array}{c}0.180 * * * \\
(4.26)\end{array}$ & & $\begin{array}{c}0.173 * * * \\
(4.29)\end{array}$ \\
\hline CONSTANT & $\begin{array}{c}0.0186 * * * \\
(2.72)\end{array}$ & $\begin{array}{c}0.0434 * * * \\
(2.71)\end{array}$ & $\begin{array}{c}0.0155^{* *} \\
(2.22)\end{array}$ & $\begin{array}{c}0.0410 * * \\
(2.59)\end{array}$ & $\begin{array}{l}0.0141 \\
(1.53)\end{array}$ & $\begin{array}{c}0.0430 * * \\
(2.56)\end{array}$ \\
\hline $\mathrm{R}^{2}$ within & $5,40 \%$ & $8,68 \%$ & $5,37 \%$ & $8,67 \%$ & $6,61 \%$ & $9,82 \%$ \\
\hline $\begin{array}{l}\mathrm{R}^{2} \text { adjusted (equivalent to a } \\
\text { regression with a dummy } \\
\text { variable per firm) }\end{array}$ & $65,07 \%$ & $66,19 \%$ & $65,01 \%$ & $66,14 \%$ & $65,38 \%$ & $66,48 \%$ \\
\hline $\mathrm{F}$ & $6,08^{* * *}$ & $7,94 * * *$ & $5,53^{* * *}$ & 6,99 *** & $4,49^{* * *}$ & $6,02^{* * *}$ \\
\hline Individual Fixed-effects & Yes & Yes & Yes & Yes & Yes & Yes \\
\hline Hausman Test & $25,46^{* *}$ & $288,14 * * *$ & $25,28^{* * *}$ & $284,77 * * *$ & $33,81 * * *$ & $267,96 * * *$ \\
\hline $\begin{array}{l}\text { Fisher Test (significance of } \\
\text { individual effects) }\end{array}$ & $8,66^{* * *}$ & $3,77^{* * *}$ & $8,72^{* * *}$ & $3,80^{* * *}$ & $7,76^{* * *}$ & $3,73^{* * *}$ \\
\hline Lagrange multiplier test & $722,5 * * *$ & $66,40 * * *$ & $725,27 * * *$ & $67,44 * * *$ & $627,30 * * *$ & $68,20 * * *$ \\
\hline Temporal Fixed-effects & No & No & No & No & No & No \\
\hline $\begin{array}{l}\text { Fisher Test (significance of } \\
\text { temporal effects) }\end{array}$ & 1,45 & 1,55 & 1,33 & 1,54 & 1,18 & 1,41 \\
\hline
\end{tabular}

$*, * *, * * *$ significant at the $10 \%, 5 \%$ and $1 \%$ level, respectively

F: Fisher Test

Coefficients are followed by $\mathrm{t}$-values into brackets. T-values are robust to heteroscedascticity, non-normality and intra-group correlation.

$\mathbf{R}^{2}$ « within » gives an idea of the part of the dependant variable's intra-individual variability explained by the independent variables. This $\mathrm{R}^{2}$ is often smaller compared to $\mathrm{R}^{2}$ deducted from OLS regressions.

$\mathbf{R}^{2}$ adjusted is issued from OLS regressions with N-1 firms' dummy variables. Because of the introduction of dummy variables, it gives a high evaluation of the explanatory power of the regression.

Though, we give a low evaluation ( $R^{2}$ within $)$ and a high evaluation $\left(R^{2}\right.$ with dummy variables) of the explanatory power of the regressions.

We square the two variables CONCONT and CONTDIR to test the existence of a non linear relationship with payout. Indeed, agency conflicts are strong only when shareholding concentration or managerial ownership is low or strong, suggesting a non linear relationship. 
Table 5 - Linear regressions on average data of payout yield over agency conflicts determinants

Dependant variable $=$ TXRDT $=$ payout yield

Independent variables = OPPINVT: dummy variable $=1$ if the Tobin's $\mathrm{Q}$ is lower than 1 ; CASHFL = average cash-flow; ACTMAJ : dummy variable = 1 if the first shareholder has more than 33,3\% of the shares; PVOIRACT $=$ relative ownership of the first shareholder compared to the other known shareholders; PVOIR2: dummy variable $=1$ if the chairman or the CEO is one of the three first shareholders; PVOIR3: dummy variable $=1$ if the main shareholder is one of the founders; FONDCA1: dummy variable $=1$ if the founder of the company is a director; LOGAPI = size of the firm.

\begin{tabular}{|c|c|c|c|}
\hline & (1) & (2) & (3) \\
\hline OPPINVT & $\begin{array}{c}0.0101 * * * \\
(4.06)\end{array}$ & $\begin{array}{c}0.0105 * * * \\
(4.33)\end{array}$ & $\begin{array}{c}0.00961 * * * \\
(4.12)\end{array}$ \\
\hline CASHFL & $\begin{array}{c}0.0825 * * * \\
(4.46)\end{array}$ & $\begin{array}{c}0.0839 * * * \\
(4.31)\end{array}$ & $\begin{array}{c}0.0820 * * * \\
(4.24)\end{array}$ \\
\hline АСТМАЈ & $\begin{array}{c}0.00385 \\
(1.36)\end{array}$ & $\begin{array}{c}0.00396 \\
(1.35)\end{array}$ & $\begin{array}{c}0.00359 \\
(1.27)\end{array}$ \\
\hline PVoIract & $\begin{array}{c}-0.0000432 \\
(-0.92)\end{array}$ & $\begin{array}{c}-0.0000319 \\
(-0.66)\end{array}$ & $\begin{array}{c}-0.0000379 \\
(-0.83)\end{array}$ \\
\hline PVOIR2 & $\begin{array}{c}-0.00747 * * \\
(-2.52)\end{array}$ & & \\
\hline PvoIR3 & & $\begin{array}{c}-0.00565 * * \\
(-2.02)\end{array}$ & \\
\hline FONDCA1 & & & $\begin{array}{c}-0.00881 * * * \\
(-3.07)\end{array}$ \\
\hline LOGCAPI & $\begin{array}{c}0.00168^{* * *} \\
(2.13)\end{array}$ & $\begin{array}{c}0.00223 * * * \\
(3.01)\end{array}$ & $\begin{array}{c}0.00168 * * \\
(2.14)\end{array}$ \\
\hline Constant & $\begin{array}{c}-0.00776 \\
(-0.65)\end{array}$ & $\begin{array}{l}-0.0174 \\
(-1.62)\end{array}$ & $\begin{array}{c}-0.00653 \\
(-0.55)\end{array}$ \\
\hline $\mathbf{R}^{2}$ adjusted & $29,28 \%$ & $28,13 \%$ & $31,07 \%$ \\
\hline $\mathbf{F}$ & $17,91 * * *$ & $15,45 * * *$ & $16,35 * * *$ \\
\hline
\end{tabular}

$*, * *, * * *$ significant at the $10 \%, 5 \%$ and $1 \%$ level, respectively

F: Fisher Test.

Coefficients are followed by t-values into brackets. T-values are robust to heteroscedascticity and non-normality of residuals.

\section{$\underline{\text { Discussion }}$}

Our results underline the various effects of agency conflicts on pay out policies.

First of all, the conflict between majority and minority shareholders influences the determination of payout policies. The presence of a majority shareholder and its "power" have a negative effect on the payout yield. The fact that the first shareholder is a manager or a founder enables him to lower payout. Moreover, we showed the negative effect of the relative power of the first shareholder. The more the first shareholder owns shares compared to others, the lower will the payout be.

The strong influence of the conflict between majority and minority shareholders puts into question the theoretical beneficial effect of the presence of large shareholders. In France, and 
probably in all the countries with concentrated ownership, the presence of large investors leads more to a risk of minority expropriation, than to an increased monitoring of managers.

Moreover, the regressions show a concave decreasing relation between the concentration of control and payout. Indeed, only the squared CONCONT variable is significant (at the $10 \%$ level). Thus, the effect of control on payout is weak when it is dispersed and stronger when it is concentrated. This result shows once more the strong and negative influence of the conflict between majority and minority shareholders on payout, but also the positive and weaker influence of the conflict between shareholders and managers.

The risk of Free Cash-flow also significantly and strongly influences payout policies. The level of payout of a firm is negatively related to its investment opportunities and positively related to its cash-flows. The greater the risk of expropriation, the larger is payout.

Thus, our results show that when facing a risk of Free Cash Flow and to a lesser extent a conflict between shareholders and managers, the payout increases, showing its use as a governance mechanism. However, when conflicts between majority and minority shareholders are important, the payout decreases showing that it is not used to regulate these conflicts. So we wonder what determines, in France, the use of payout policies as a governance mechanism.

In this paper, we made the hypothesis that the use of payout policies as a governance mechanism depended on the existence and use of other governance mechanisms. Our empirical study confirmed the influence of various governance mechanisms on payout policies.

We found a negative influence of debt on payout. Moreover, our results show that the control exerted by blockholders, and more specifically the second largest shareholder, has a negative influence on payout policies. This can result from a substitution between payout and control of the second shareholder, but also from the fact that the second shareholder takes part in the expropriation of minority shareholders. That certainly depends from the identity of the second shareholder. A deeper analysis would be necessary to settle this issue.

Concerning the board of directors, its quality only slightly influences payout policies. The presence of independent directors encourages payout decisions, whereas the presence of the founder at the board decreases the payout yield. The other characteristics of the board don't influence payout.

Thus, in front of a free cash-flow risk, external shareholders manage to claim a payout, but it seems that in the presence of a main shareholder, it is more difficult for them to ask for repurchases or dividends. According to our model, this can be explained by the existence and use of the other governance mechanisms.

In face of governance mechanisms substituting to payout, the use of the dividend and repurchase should drop. We identified two mechanisms having a negative influence on payout: debt and the control of the second shareholder. Do those mechanisms efficiently regulate the majority/minority conflicts, but not conflicts resulting from the risk of Free Cashflow or divergences between shareholders and managers? That would explain the drop in payout in the first case and its rise in the others.

- $\underline{\text { Debt }}$ acts on Free Cash-flow by the same mechanisms as payout. It is then logical that these two instruments are not used together when facing a risk of Free Cash-flow. The low level of French companies' debt (in our sample, the average and median "total debts /total assets" 
ratio is 25\%) can partly explain the recourse to payout in front of a risk of Free Cash-flow. Meanwhile, debt explains with difficulty the decrease in dividend paid in the presence of conflicts between majority and minority shareholders.

- The influence of the monitoring exerted by the second shareholder on the payout yield is globally negative, but certainly depends on the shareholder identity. Then, second shareholders would not have a single influence and could not explain the differentiated use of payout whether the company is confronted to a risk of Free Cash-flow or to a conflict between majority and minority shareholders.

In face of governance mechanisms complementary to payout, the use of the dividend and repurchase should increase. We made the hypothesis that managers only decide to pay out if complementary mechanisms force them to it. Indeed, in the absence of such mechanisms, their interest is to minimize payout in order to extract private benefits.

Our results lead us to think that there may be effective mechanisms to force payouts when there is an important risk of Free Cash-flow or a conflict between shareholders and managers, but not in the presence of a conflict between majority and minority shareholders.

Our review of literature enabled us to make the hypothesis of the existence of several complementary governance mechanisms: legislation, pressure exerted by the stock market and the board of directors. Our empirical study did not show others.

- The board of directors, as the principal decision maker of payout policies, should influence them. However, our results showed the neutrality of the majority of board's characteristics. Literature shows that the effectiveness of the control exerted by the board is weakened by the presence of a controlling shareholder. In this situation, the board has little autonomy and is often entrenched and controlled by majority shareholders.

The weakness of the board's influence on payouts explains that in face of a conflict between majority and minority shareholders, payout decreases, and only slightly increases in the event of a conflict between shareholders and managers. In this case, payout is increased because without a controlling shareholder, it is easier for minority shareholders to defend their interests.

- The influence of legislation and of legal protection of minority shareholders has not been studied empirically here. However, the research made in this field, clearly underlined the positive influence of legislation on the level of payout (La Porta et al., 2000; Faccio et al., 2001). La Porta et al. (2000) consider France and the countries of French civil law as insufficiently protective of minority shareholders.

This classification, although a little arbitrary, finds however echo in our results. In the presence of agency conflicts, it is difficult for an external shareholder to push internal actors to pay out. Again, that explains that the payout is lowered in the presence of agency conflicts between majority and minority shareholders, in spite of the fact that it can constitute a governance mechanism.

The weakness of the role of the board and the insufficiency of legal protection explain the decrease of payout in presence of agency conflicts between majority and minority shareholders. However, they explain with more difficulty the increase of payouts in face of a conflict between managers and shareholders, or a risk of Free Cash-flow. In order to deepen this point, we discuss the influence of the last complementary governance mechanism: the equity market.

Influence of capital markets was supposed to be weak in France. Indeed, the risk of takeover is limited and the direct influence of markets on each company is weak. However, the 
influence of markets can be more general and pass through media, financial analysts or rating agencies...

For example, the market distinguishes "growth stocks" from "yield stocks". The first are companies having a strong potential growth and for which payout is not important, whereas for "yield stocks", dividend policy is determining for investors. This distinction certainly influences managers at the time of their payout decision. Therefore, a company known as "yield" will have to pay out not to be penalized by investors. In face of a high Free Cash-flow risk, firms are prompt by the markets to pay out.

Meanwhile, when ownership is concentrated, it does not seem that markets exert pressure towards payouts. Is it because they do not suspect the existence of conflicts? Is their influence ineffective? Or is it because it is legitimate, for a French investor, that a large shareholder extracts private benefits?

For 15 years, the development of "rules" of good governance has focused, under the influence of the Anglo-Saxon markets, on the conflict between shareholders and managers. Then, the market is probably more sensitive to the risk of expropriation by managers, than by controlling shareholders. That would explain the differentiated use of payout policies depending on the type of conflicts.

\section{CONCLUSION}

Our study sheds light on the place of payout policies in corporate governance systems. We showed that payout policies can help to regulate agency conflicts between minority shareholders, managers and controlling shareholders. But, in France, the use of payout as a governance tool is slowed down by the absence of alternate mechanism forcing the internal actors to adopt such policies. The conflict between majority and minority shareholders is poorly supervised and does not cause sufficient payout compared to the risk of expropriation incurred by minority shareholders. But the risk of Free Cash-flow and to a lesser extent conflicts between shareholders and managers might cause a reaction of the markets or be better apprehended by boards. It then leads to an increase in payouts in the presence of such conflicts.

Therefore, payout policy is, in theory, a governance mechanism, but its use in the presence of agency conflicts is moderated in France. To facilitate the use of pay out policies, it seems necessary to improve French corporate governance and to develop alternate governance mechanisms. 


\section{BIBLIOGRAPHY}

Barca, F. \& Becht, M. (2001). The Control of Corporate Europe. Oxford: Oxford University Press.

Billett, M. T. \& Xue, H. (forthcoming). The takeover deterrent effect of open market share repurchases. Journal of Finance.

Brav, A., Graham, J. R., Harvey, C. R. \& Michaely, R. (2005). Payout policy in the 21st century. Journal of Financial Economics, 77 (3), 483-527.

Carleton, W. T., Nelson, J. N. \& Weisbach, M. S. (1998). The influence of institutions on corporate governance through private negociations: evidence from TIAA-CREF. Journal of Finance, 53 (4), 1335-1362.

Del Guercio, D. \& Hawkins, J. (1999). The motivation and impact of pension fund activism. Journal of Financial Economics, 52, 293-340.

Denis, D. K. \& McConnell, J. J. (2003). International corporate governance. Journal of Financial and Quantitative Analysis, 38 (1).

Easterbrook, F. H. (1984). Two agency-cost explanations of dividends. American Economic Review, 74 (4), 650-659.

Faccio, M., Lang, L. \& Young, L. (2001). Dividends and expropriation. American Economic Review, 91 (1).

Fama, E. F. \& Jensen, M. (1983). Separation of ownership and control. Journal of Law \& Economics, 26 (2), 301-326.

Farinha, J. (2003). Dividend policy, corporate governance and the managerial entrenchment hypothesis: an empirical analysis. Journal of Business Finance and Accounting, 30 (9/10), 1173-1209.

Fenn, G. \& Liang, N. (2001). Corporate payout policies and managerial stock incentives. Journal of Financial Economics, 60, 45-72.

Girard, C. (2001). Une typologie de l'activisme des actionnaires minoritaires en France. Finance Contrôle Stratégie, 4 (3), 123-146.

Gugler, K. \& Yurtoglu, B. (2003). Corporate governance and dividend pay out policy in Germany. European Economic Review, 47 (4), 731-758.

Hausman, J. (1978). Specification tests in econometrics. Econometrica, 46, 1251-1271.

Holderness, C. G. (2003). A survey of blockholders and corporate control. Economic Policy Review, 9 (1), 51-63.

Hu, A. \& Kumar, P. (2004). Managerial entrenchment and payout policies. Journal of Financial and Quantitative Analysis, 39 (4), 759-790.

Jensen, M. (1986). Agency costs of free cash flow, corporate finance, and takeovers. American Economic Review, 76 (2), 323-329.

Jensen, M. (1993). The modern industrial revolution, exit, and the failure of internal control systems. Journal of Finance, 48 (3), 831-880.

Jensen, M. \& Meckling, W. H. (1976). Theory of the firm: managerial behavior, agency costs and ownership structure. Journal of Financial Economics, 3 (4), 305-360.

Klein, A. (1998). Firm performance and board committee structure. Journal of Law \& Economics, 41 (1), 275-303.

La Porta, R., Lopez-de-Silanes, F. \& Shleifer, A. (1999). Corporate ownership around the world. Journal of Finance, 54, 471-517.

La Porta, R., Lopez-de-Silanes, F., Shleifer, A. \& Vishny, R. W. (1998). Law and finance. Journal of Political Economy, 106 (6), 1113-1155. 
La Porta, R., Lopez-de-Silanes, F., Shleifer, A. \& Vishny, R. W. (2000). Agency problems and dividend policies around the world. Journal of Finance, 55 (1), 1-33.

Maati, J. (1999). Le Gouvernement d'Entreprise. DeBoeck Université.

Manne, H. G. (1965). Mergers and the market for corporate control. Journal of Political Economy, 73 (2), 110-120.

Maury, B. \& Pajuste, A. (2002). Controlling shareholders, agency problems and dividend policy in Finland. The Finish Journal of Business Economics, 51 (1).

McConnel, J. \& Servaes, H. (1990). Additional evidence on equity ownership and corporate value. Journal of Financial Economics, 27, 595 - 612.

Morck, R. A., Shleifer, A. \& Vishny, R. W. (1988). Management ownership and market valuation: an empirical analysis. Journal of Financial Economics, 20, 293-315.

Morck, R. A., Shleifer, A. \& Vishny, R. W. (1989). Alternative mechanisms for corporate control. American Economic Review, 79, 842-852.

Nenova, T. (2003). The value of corporate voting rights and control: a cross-country analysis. Journal of Financial Economics, 68 (3), 325-351

Oswald, D. \& Young, S. (2005). Open market share reacquisitions, surplus cash, and agency problems. AFA annual meeting.

Page, D. E., Jahera, J. S. \& Pugh, W. N. (1996). The effect of takevoer defenses on the dividend decision. Journal of Economics and Finance, 20 (3), 49-58.

Palmon, O. \& Wald, J. K. (2002). Are two heads better than one? The impact of changes in management structure on performance by firm size. Journal of Corporate Finance, 8 (3), 213-226.

Renneboog, L. \& Trojanowski, G. (2005). Control structures and payout policy.Working Paper European Corporate Governance Institute (ECGI) - Finance nº8/2005.

Shleifer, A. \& Vishny, R. W. (1986). Large shareholders and corporate control. Journal of Political Economy, 94 (3), 461-488.

Shleifer, A. \& Vishny, R. W. (1997). A survey of corporate governance. Journal of Finance, 52 (2), 737-783.

Singh, M. \& Davidson, W. N. (2003). Agency costs, ownership structure and corporate governance mechanisms. Journal of Banking and Finance, 27 (5), 793-816.

Smith, M. P. (1996). Shareholder activism by institutional investors: evidence from CalPERS. Journal of Finance, 51 (1), 227-252.

Stulz, R. (1988). Managerial control of voting rights: financing policies and the market for corporate control. Journal of Financial Economics, 20 (1/2), 25-54.

Tirole, J. (2006). The Theory of Corporate Finance. Princeton University Press.

Weisbenner, S. (2002). Corporate share repurchases in the 1990s: What role do stock options play? AFA annual Meetings. Atlanta

Zwiebel, J. (1996). Dynamic capital structure under managerial entrenchment. American Economic Review, 86, 1197-1215. 